\title{
ECONOMIC EFFICIENCY OF EXTENSIVE LIVESTOCK PRODUCTION IN THE EUROPEAN UNION ${ }^{1}$
}

\author{
Lana Nastic ${ }^{2}$, Todor Markovic ${ }^{3}$, Sanjin Ivanovic ${ }^{4}$
}

\begin{abstract}
Summary
Various types of extensive livestock production are present worldwide, primarily in regions where natural resources such as pastures and meadows could be used. Extensive livestock production is common in the EU, as well. Therefore the goal of this research was to establish economic efficiency of extensive livestock production types and to compare their efficiency with some intensive livestock production types. In order to achieve that goal FADN (Farm Accountancy Data Network) methodology was used. Source of information was FADN database as well as appropriate sector analysis and publications of European commission. It has been determined that sheep and goat production is competitive with intensive production types (dairy and granivores - pigs and poultry). Cattle production (other than dairy production) proved to be economically inefficient due to low output level.
\end{abstract}

Key words: extensive livestock farming, FADN, productivity, return on assets

JEL: $Q 12$

\section{Introduction}

Comparing to intensive form of livestock production, extensive livestock production has a lot of advantages, but the main one is its sustainability. Extensive livestock

1 Paper is a part of the research at the project no. III 46006 - Sustainable agriculture and rural development in the function of accomplishment of strategic goals of the Republic of Serbia within the Danube region, and project TR-31051 - Improvement of biotechnological procedures as a function of rational utilization of energy, agricultural products productivity and quality increase, financed by the Ministry of Education, Science and Technological Development of the Republic of Serbia, for the project period 2011-2014.

2 Lana Nastic M.A., Researcher Assistant, Institute of Agricultural Economics, Volgina Street no. 15, 11060 Belgrade, Republic of Srbija, Phone: +381 116972 852, E-mail: lana_n@iep.bg.ac.rs.

3 Todor Markovic Ph.D., Associate Professor, University of Novi Sad, Trg Dositeja Obradovica no. 8, Novi Sad, Republic of Serbia, Phone: +381 214853 500, E-mail: todor.markovic@polj.edu.rs.

4 Sanjin Ivanovic Ph.D., Associate Professor, University of Belgrade, Faculty of Agriculture, Nemanjina Street no. 6, 11080 Zemun, Republic of Srbija, Phone: +381 114413 426, E-mail: sanjinivanovic@agrif.bg.ac.

EP 2017 (64) 3 (1219-1230) 
production is characterised by better use of natural resources (primarily pastures) and local livestock breeds which are better accommodated to the environment and better connected to local tradition. Such approach has a lot of other benefits for entire human society described by Eisler et al. (2014). Research which has been done by the FAO showed that future development of livestock production should be performed via programmes which are carefully adjusted to specific local conditions, while global developmental programmes would lead to bad and unsuccessful developmental solutions (Otte et al., 2012).

Extensive types of cattle production (usually called beef cow-calf production systems) are present worldwide, especially in countries rich in pastures and meadows. There is a lot of research dealing with technical (herd size, mortality, age of owner) and economic efficiency indicators of extensive cattle production (total investments, total costs, production value, total profit and profit per cow, salary per cow breakeven point, rate of return) and appropriate breeds for this type of production (Davis et al., 1994; Ramsey et al., 2005; Miller et al., 2001; Ward et al., 2008). Most of the authors use standardised performance analysis to determine the most important factors with influence on economic effects of this production. To examine above mentioned problems it is necessary to use appropriate software, but to provide conclusive results the software (model) has to be tested, as well (Tess and Kolstad, 2000).

In Japan extensive cattle production is very often analysed in terms of environmental protection, fodder production and transportation, manure treatment, gas emission (Ogino et al., 2007; Kazato et al., 2013). This production type is very important in tropical South - American regions (primarily in Brazil) so that special attention is paid to connection between cattle ranching and rehabilitation of tropical forest (Murgueitio et al., 2011; Bowman et al., 2012).

Sheep breeding is considered as extensive livestock production, as well. It is also based on use of pastures and therefore countries such as New Zealand are big producers and exporters of mutton and lamb. Therefore, economic effects of this production depend on free international trade and potential export barriers (Morris, 2009). Competitiveness of various types of sheep production is also very important in Australia (Kopke et al., 2008) as well as in many countries in tropical area (Kosgey et al., 2006). Authors determined that introduction of new technologies in sheep production primarily depend on their simplicity. New technologies in sheep production also have to be affordable (cheap), and related to low level of risk.

Special types of extensive sheep production are present in some European countries. Good example is so called "dehesa system" in Spain. This system is combination of pastures and oak wood used for combination of sheep production, beef production and swine production (so called Iberian pigs). In such circumstances type of farming depends on combination of various livestock and management practices (Gaspar et al., 2008). On the other side, examination of technical efficiency of such farms led to the conclusion that the farms with the best use of pastures have the highest efficiency (Gaspar et al., 
2009). Dehesa system is not the only extensive sheep production system in Spain. There are some other production systems which combine sheep and goat production and use of pastures, primarily in north - west region of Spain. According to the results of the research (Jauregui et al., 2007) there are various management strategies for these pastures (they are used only by sheep, only by goats, or by some combination of sheep and goats).

In the most developed countries of the European Union (for example in the United Kingdom) a lot of attention is paid to animal welfare in sheep production. Authors stated (Stott et al., 2005) that intensification of production led to increased competitiveness, but at the same time decreased animal welfare. On the other side, improvement of animal welfare has negative influence on profit in sheep production. But another author examined similar problem in Australia and reached completely opposite conclusion (Kingwell, 2002). Having in mind animal welfare, an author (Hemsworth, 2003) suggests certain tests and education for workers who work in direct contact with animal in order to reduce stress for animals and to increase their productivity. Increase of animal welfare is related to increased engagement of farm managers during some crucial stages of production process, for example in disease control (Goddard et al., 2006).

Goat production is by definition extensive and exists primarily in poor and developing countries. In the EU goat production is primarily directed towards milk production. The most important EU countries regarding number of goats (and volume of goat milk production) are Spain, France and Greece (Aziz, 2010), while the highest number of goats is present in Greece (Kitsopanidis, 2002). Number of goats increases in Australia, while number of sheep at the same time decreases (Clarke and Ronning, 2013). The reason for this phenomenon is export of goat meat from Australia to the United States (Febrianno and Siahaan, 2012). On the other hand, the EU countries import sheep and goat meat mostly from New Zealand. Due to high demand, goat meat production has been increasing in the United States, as well. The main area for goat meat is south-east of the US because of its arid climate and sufficient quantities of appropriate fodder (Qushim et al., 2016).

The importance of livestock production could be seen from Table 1. representing number of such farms in the EU and their number in FADN sample.

Table 1. Number of holdings in the EU by type of farming in 2012

\begin{tabular}{|l|c|c|}
\hline \multirow{2}{*}{ Types of farming } & Farms represented & Sample farms \\
\cline { 2 - 3 } & Sum & Sum \\
\hline Field crops & 1120030 & 23820 \\
\hline Horticulture & 185840 & 5146 \\
\hline Wine & 278840 & 4456 \\
\hline Other permanent crops & 688340 & 6649 \\
\hline Milk & 605080 & 14121 \\
\hline Grazing livestock & 807400 & 11368 \\
\hline Granivores & 170050 & 5785 \\
\hline
\end{tabular}




\begin{tabular}{|l|c|c|}
\hline Mixed (crops and livestock) & 1063780 & 11951 \\
\hline Total groups & 4919360 & 83296 \\
\hline
\end{tabular}

Source: European Commission (2015): EU Farm Economics Overview based on 2012 FADN data.

There are 807,400 farms in the EU dealing with grazing livestock (sheep and goat production type and cattle production type - cattle other than dairy cows). Beside there are 605,080 farms engaged in milk production and 170,050 farms in type - granivores. It is evident that farms which have grazing livestock production type (extensive production) outnumber farms with intensive livestock production (milk and granivores).

The goal of this paper is comparison of various economic efficiency indicators among extensive livestock production (sheep and goat production, cattle production) and intensive types of livestock production (dairy and granivores - pigs and poultry). On the basis of the analysis it will be possible to determine whether extensive livestock production types are competitive with the intensive ones.

\section{Material and methods}

In order to analyse economic effectiveness of extensive livestock farms in the European Union data from FADN database (based on Commission Regulation (EC) No. 868/2008), which provide large number of various analyses, are primarily used. Besides, it is possible to follow absolute, as well as relative indicators of economic effectiveness (total output/total input, farm net income/total assets, farm net value added/ AWU). FADN is a unique accountancy methodology for all agricultural producers in the European Union and it is organised by adequate European Commission regulations. Last available data in FADN database refer to 2013. Data from following years have not been published yet.

The research also relies on sector analysis published by the European Commission which is also based on FADN data. Sector analysis covers four year period (from 2010 to 2013) and four production types (sheep and goat, cattle, dairy, granivores).

\section{Results and discussion}

One of the most important indicators of economic effectiveness of production (Graph 1.) is total output/total input (productivity). This indicator, as well as other indicators used in this research, gives an opportunity to compare farms of different sizes and production types. During entire observed period productivity of cattle production (type of cattle production which is not primarily based on milk production) is the lowest and constantly under 1 (total output is lower than total input). On the other side, productivity of sheep and goat production is very high (the highest of all observed production types in 2010 and 2011) and competitive to productivity of dairy and granivores. 
Graph 1. Productivity of various livestock production types

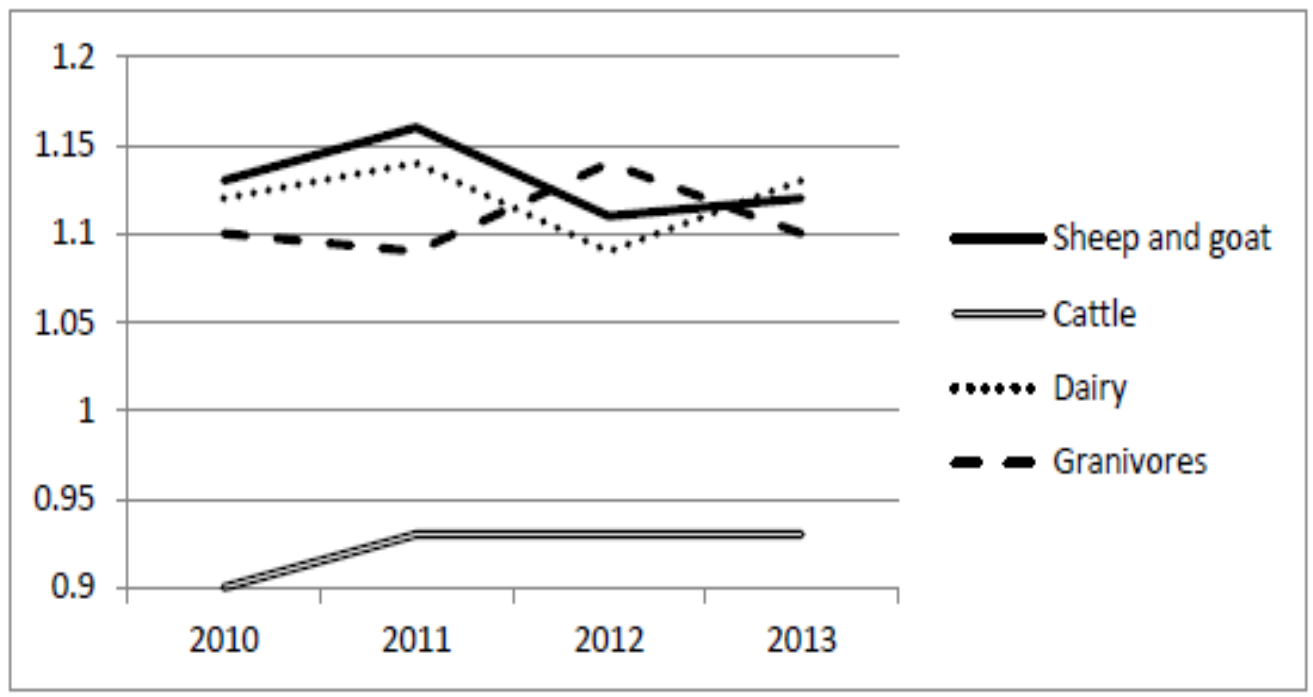

Source: http://ec.europa.eu/agriculture/rica/database/database en.cfm and authors' calculation At the same time it is necessary to have in mind that sheep and goat farms are the smallest farms regarding volume of total output and total input. For example, total output of sheep and goat farms ranges from 31,000 and 33,000 EUR while total output of granivores ranges from 236,000 to 238,000 EUR (Table 2.).

Table 2. Total output of various livestock production types

\begin{tabular}{|c|c|c|c|c|}
\hline & Sheep and goat & Cattle & Dairy & Granivores \\
\hline 2010 & 31,000 & 49,900 & 97,400 & 236,200 \\
\hline 2011 & 33,400 & 53,100 & 110,100 & 253,300 \\
\hline 2012 & 33,700 & 57,100 & 104,300 & 279,800 \\
\hline 2013 & 33,600 & 59,200 & 105,500 & 278,600 \\
\hline
\end{tabular}

Source: http://ec.europa.eu/agriculture/rica/database/database_en.cfm

Sheep and goat production type has even better results concerning return on assets (farm net income/total assets) comparing to other livestock production types (Graph 2.). Contrary to that in most of the observed years return on assets is the lowest in cattle production (under $4 \%$ ). 
Graph 2. Return on assets of various livestock production types

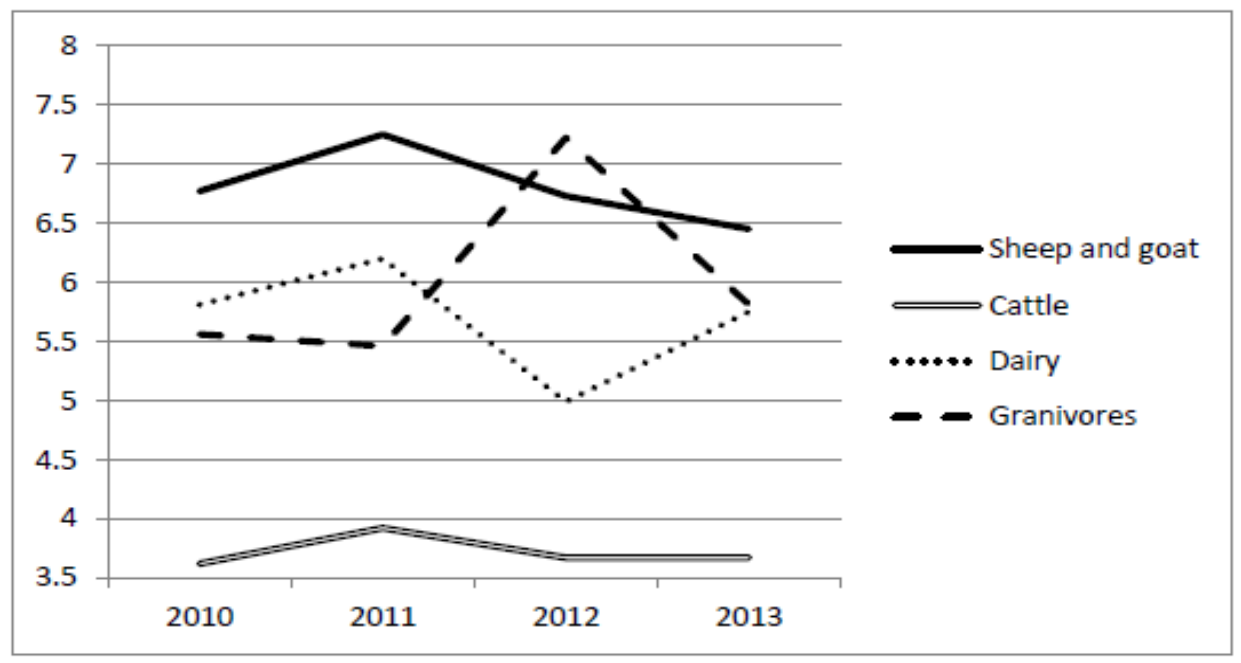

Source: http://ec.europa.eu/agriculture/rica/database/database_en.cfm and authors' calculation

The reason for so high return on equity in sheep and goat production are primarily very small total assets in this production (Table 3.).

Table 3. Total assets of various livestock production types

\begin{tabular}{|c|c|c|c|c|}
\hline & Sheep and goat & Cattle & Dairy & Granivores \\
\hline 2010 & 188,900 & 427,600 & 471,900 & 607,400 \\
\hline 2011 & 193,000 & 423,800 & 496,700 & 614,000 \\
\hline 2012 & 193,000 & 425,400 & 468,600 & 626,000 \\
\hline 2013 & 196,900 & 438,900 & 453,800 & 640,500 \\
\hline
\end{tabular}

Source: http://ec.europa.eu/agriculture/rica/database/database en.cfm

Productivity and ROA (return on assets) indicator lead to a conclusion that small family farms oriented towards sheep and goat production are very economically efficient comparing to much bigger dairy farms, pig farms and poultry farms. On the other hand extensive cattle farming is not economically efficient. So, one type of extensive production is very economically acceptable (sheep and goat) while the other one (cattle) is not. The question is - what is the reason for unfavourable results of cattle production?

If dairy and cattle productions are compared, it is obvious that value of their total assets is very similar (in 2013 it is approximately 250,000 EUR) which means that the reason for low ROA indicator for cattle production is very small farm net income (FNI). Return on assets measures the effectiveness of a farm's assets in generating revenue. According to European Commission (2015) report low ROA means that farms "invested a high amount of capital into their production, while simultaneously receiving 
little income". According to above mentioned analysis this could be linked to decrease in production volume or decrease in prices of animal products.

Small income in cattle production could be seen in one more important indicator of economic efficiency - total livestock output per livestock unit (LU). This indicator (Graph 3.) is the lowest in cattle production during entire observed period. Although value of total assets is almost equal in cattle and dairy production, total livestock output/LU is approximately twice bigger in dairy production.

Graph 3. Total livestock output/LU for various production types

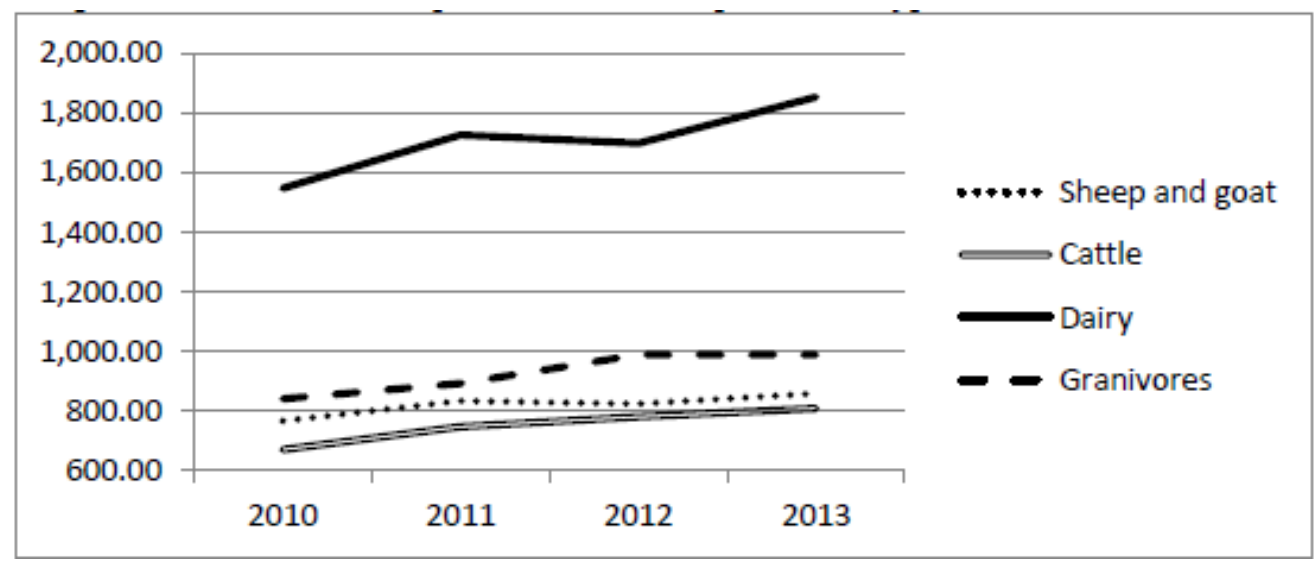

Source: http://ec.europa.eu/agriculture/rica/database/database en.cfm and authors' calculation

To compare productivity of agricultural labour among various production types FADN methodology usually uses following indicator - farm net value added/annual work unit (FNVA/AWU). Farms specialized in granivores have had the highest FNVA/AWU in all observed years (Graph 4.).

Graph 4. FNVA/AWU for various production types (EUR 000/AWU)

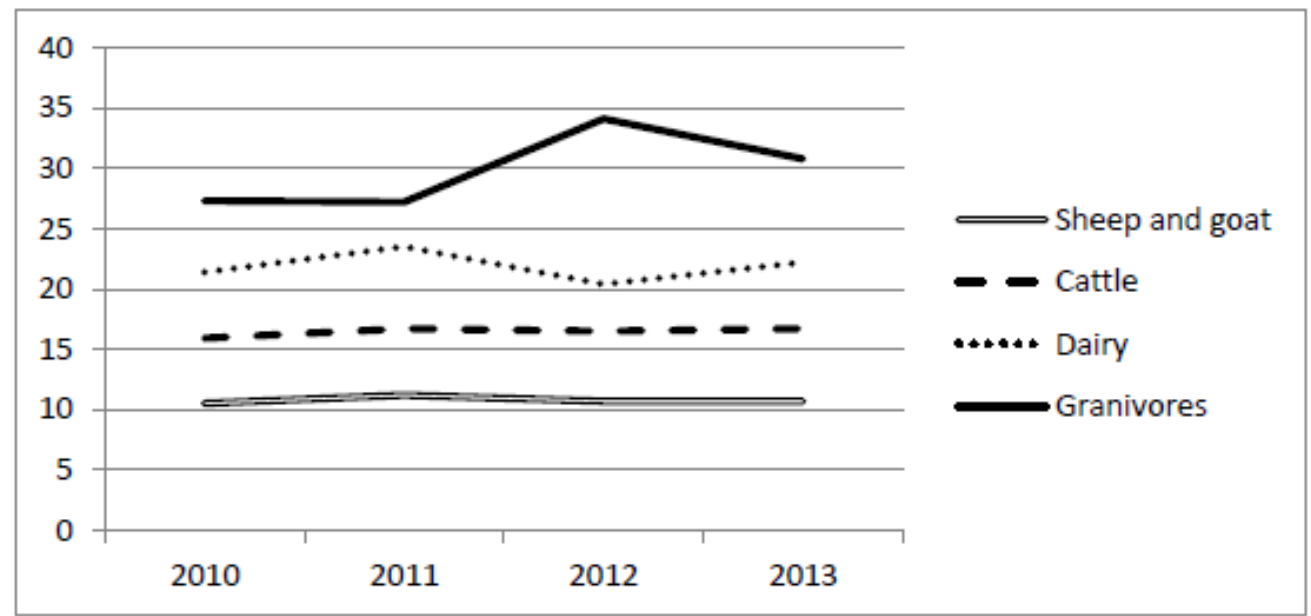

Source: http://ec.europa.eu/agriculture/rica/database/database en.cfm and authors' calculation EP 2017 (64) 3 (1219-1230) 
As expected, the biggest farms with intensive production (granivores) had the highest FNVA per average work unit. Small farms with extensive production (low investments in fixed assets) have the lowest productivity of agricultural labour.

\section{Conclusion}

This paper analysed two types of extensive livestock production and compared them to two types of intensive livestock production. As it was expected, extensive production types had the lowest productivity of agricultural labour. In terms of other indicators (productivity, return on assets) extensive types of livestock production (sheep and goat compared to cattle) had different values of above mentioned indicators. Small sheep and goat farms are very competitive with big farms which have intensive production (dairy and granivores). On the other hand cattle farms have smaller output than input. This is primarily caused by discrepancy between levels of invested capital and total output.

Research results referring to the EU are significant for the agriculture of the Republic of Serbia as well. They indicate the need to analyse cattle production in Serbia more thoroughly because this production type has not been developed enough yet. Farmers who plan to become involved in cattle production in Serbia (other than dairy production) have to be aware of the necessity to keep investments in this production at a very low level. Otherwise, there is high probability that cattle production in Serbia will not be economically efficient. On the other hand, successfulness of small sheep and goat farms in the EU indicates that they could be competitive to large scale dairy and granivores operation. Having this in mind, it might be expected that small sheep and goat farms in Serbia will be competitive to other types of livestock production in the future.

\section{Literature}

1. Aziz M. A. (2010): Present status of the world goat populations and their productivity. Lohmann Information, ISSN 1617-2906, Volume 45, No. 2, Oct. 2010, pp. 42-52. (available at: http://lohmann-information.de/content/1_i 45 artikel17. pdf).

2. Bowman, M.S., Soares-Filho, B. S., Merry, F. D., Nepstad, D. C., Rodrigues, H., Almeida, O. T. (2012): Persistence of cattle ranching in the Brazilian Amazon: A spatial analysis of the rationale for beef production. Land Use Policy, ISSN 02648377, Volume 29, Issue 3, July 2012, doi: 10.1016/j.landusepol.2011.09.009, pp. 558-568. (available at: http://www.sciencedirect.com/science/article/pii/ $\underline{\mathrm{S} 0264837711001037) .}$

3. Clarke, M., Ronning, D. (2013): Goat meat industry RD\&E strategy - 2012 benefit cost analysis. Meat \& Livestock Australia Limited. ISBN 9781741919929. (available at: https://www.mla.com.au/CustomControls/PaymentGateway/ViewFile.aspx?ZRx8U1iEOwSwUaIBSZT+Ts1iGZaDWRPpRHMppRRjrLxlghY501Uq4Ekmoqk3kNLh3

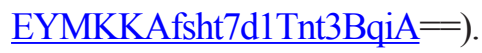


4. European Commission (2015): EU Farm Economics Overview based on 2012 FADN data. (available at: http://ec.europa.eu/agriculture/rica/pdf/EU FEO FADN 2013 final web.pdf).

5. Commission Regulation (EC) No. 868/2008 of 3 September 2008 on the farm return to be used for determining the incomes of agricultural holdings and analyzing the business operation of such holdings. (available at: file://D:/Admin/Downloads/03\%20Reglament868-2008-FarmReturn\%20(2).pdf).

6. Davis, K., C; Tess, M. W., Kress, D. D., Doornbos, D. E., Anderson, D. C. (1994): Life cycle evaluation of five biological types of beef cattle in a cow-calf range production system: II. Biological and economic performance, Journal of animal science, ISSN 0021-8812, Volume 72, No. 10, doi:/1994.72102591x, pp. 25912598. (available at: https://dl.sciencesocieties.org/publications/jas/abstracts/72/1 $\underline{0 / 2591 \text { ? access }=0 \& \text { view }=p d f)}$.

7. Eisler, M. C., Lee, M. R., Tarlton, J. F., Martin, G. B., Beddington, J., Dungait, J. A., Greathead, H., Liu, J., Mathew, S., Miller, H., Misselbrook, T., Murray, P., Vinod, K. V., Saun V. R., Winter, M. (2014): Agriculture: Steps to sustainable livestock. Nature, Volume 507, Issue 7490, Nature, ISSN 0028-0836, pp. 32-34. (available at: http://www.nature.com/polopoly fs/1.14796!/menu/main/topColumns/topLeftColumn/pdf/507032a.pdf).

8. Febrianno, E., Siahaan, U. (2012): Investment Analysis on Goat and Sheep Fattening Project Based on the New Food Fermentation Farming Method (3F Method). The Indonesian Journal of Business Administration. ISSN 2252-3464, Volume 1, No. 9, pp. 613-621. (available at: http://journal.sbm.itb.ac.id/index.php/IJBA/article/view/445).

9. Farm economy focus by sector "Farms Specialized in Sheep and Goats in the EU" Based on FADN data up to 2013. European Commission. (available at: https:// ec.europa.eu/agriculture/sites/agriculture/files/agriculture/sheep-goat_en.pdf).

10. Farm economy focus by sector "Farms Specialized in Cattle in the EU" Based on FADN data up to 2013. European Commission. (available at: https://ec.europa.eu/ agriculture/sites/agriculture/files/agriculture/cattle en.pdf)

11. Farm economy focus by sector "Dairy Farms in the EU" Based on FADN data up to 2013. European Commission. (available at: https://ec.europa.eu/agriculture/ sites/agriculture/files/agriculture/dairy en.pdf)

12. Farm economy focus by sector "Farms Specialized in Granivores in the EU" Based on FADN data up to 2013. European Commission. (available at: https://ec.europa.eu/ agriculture/sites/agriculture/files/agriculture/granivores en.pdf).

13. Gaspar, P., Escribano, M., Mesías, F. J., de Ledesma, A. R., Pulido, F. (2008): Sheep farms in the Spanish rangelands (dehesas): Typologies according to livestock management and economic indicators. Small Ruminant Research, ISSN 0921-4488, Volume 74, Issues 1-3, doi:10.1016/j.smallrumres.2007.03.013, pp. 52-63. (avail- 
able at: http://www.sciencedirect.com/science/article/pii/S0921448807000971).

14. Gaspar, P., Mesías, F. J., Escribano, M., Pulido, F. (2009): Assessing the technical efficiency of extensive livestock farming systems in Extremadura, Spain. Livestock Science, ISSN 1871-1413, Volume 121, Issue 1, doi:10.1016/j.livsci.2008.05.012, pp. 7-14. (available at: http://www.sciencedirect.com/science/ article/pii/S1871141308001558).

15. Goddard, P., Waterhouse, T., Dwyer, C., Stott, A. (2006): The perception of the welfare of sheep in extensive systems. Small Ruminant Research, ISSN 09214488, Volume 62, No. 3, doi:10.1016/j.smallrumres.2005.08.016, pp. 215-225. (available at: http://www.sciencedirect.com/science/article/pii/S0921448805003482).

16. Hemsworth, P. H. (2003): Human-animal interactions in livestock production. Applied Animal Behaviour Science, ISSN: 0168-1591, Volume 81, Issue 3, doi:10.1016/S0168-1591(02)00280-0, pp. 185-198. (available at: http://www.sciencedirect.com/science/article/pii/S0168159102002800).

17. Jauregui, B.M., Celaya, R., García, U., Osoro, K. (2007): Vegetation dynamics in burnt heather-gorse shrublands under different grazing managements with sheep and goats. Agroforestry Systems, ISSN 0167-4366, Volume 70, Issue 1, DOI 10.1007/s10457-007-9045-x, pp. 103-111. (available at: https://link.springer. com/article/10.1007/s10457-007-9045-x).

18. Kopke, E., Young, J., Kingwell, R. (2008): The relative profitability and environmental impacts of different sheep systems in a Mediterranean environment. Agricultural Systems, ISSN: 0308-521X, Volume 96, Issues 1-3, March 2008, doi:10.1016/j.agsy.2007.06.003, pp. 85-94. (available at: http://www.sciencedirect.com/science/article/pii/S0308521X07000807).

19. Kitsopanidis, G.I. (2002): Economics of goat farming in Greece. NEW MEDIT N. ISSN 1594-5685, Volume 1, Issue 3, pp. 48-53. (available at: http://www.iamb.it/ share/img new medit articoli/210 48kitsopanidis.pdf).

20. Kingwell, R. (2002). Sheep animal welfare in a low rainfall Mediterranean environment: a profitable investment?. Agricultural Systems, ISSN 0308-521X, Volume 74, Issue 2, doi:10.1016/S0308-521X(01)00086-5, pp. 221-240. (available at: http:/www.sciencedirect.com/science/article/pii/S0308521X01000865).

21. Kosgey, I. S., Baker, R. L., Udo, H. M. J., Van Arendonk, J. A. M. (2006): Successes and failures of small ruminant breeding programmes in the tropics: a review. Small Ruminant Research, ISSN 0921-4488, Volume 61, Issue 1, doi:10.1016/j. smallrumres.2005.01.003, pp. 13-28. (available at: http://www.sciencedirect.com/ science/article/pii/S0921448805000258).

22. Miller, A. J., Faulkner, D. B., Knipe, R. K., Strohbehn, D. R., Parrett, D. F., Berger L. L. (2001): Critical Control Points for Profitability in the Cow-Calf Enterprise. Professional Animal Scientist, December 2001 vol. 17 no. 4, pp. 295-302. (available at: http:// 
www.sciencedirect.com/science/article/pii/S1080744615316430).

23. Morris, S. T. (2009): Economics of sheep production. Small ruminant research, ISSN 0921-4488, Volume 86, Issues 1-3, doi:10.1016/j.smallrumres.2009.09.019, pp. 59-62. (available at: http://www.sciencedirect.com/science/article/pii/ $\underline{\mathrm{S} 0921448809001771)}$.

24. Murgueitio, E., Calle, Z., Uribe, F., Calle, A., Solorio, B. (2011): Native trees and shrubs for the productive rehabilitation of tropical cattle ranching lands. Forest Ecology and Management, ISSN 0378-1127, Volume 261, Issue 10, doi:10.1016/j. foreco.2010.09.027, pp. 1654-1663. (available at: http:/www.sciencedirect.com/ science/article/pii/S0378112710005591).

25. Ogino, A., Orito, H., Shimada, K., Hirooka, H. (2007): Evaluating environmental impacts of the Japanese beef cow-calf system by the life cycle assessment method. Animal Science Journal, ISSN 1740-0929, Volume 78, Issue 4, DOI: 10.1111/j.1740-0929.2007.00457.x, pp. 424-432. (available at: http://onlinelibrary.wiley.com/doi/10.1111/j.1740-0929.2007.00457.x/full).

26. Ramsey, R., Doye, D., Ward, C., McGrann, J., Falconer, L., Bevers, S. (2005): Factors Affecting Beef Cow-Herd Costs, Production, and Profits. Journal of Agricultural and Applied Economics, EISSN 2056-7405, Volume 37, Issue 1, pp. 91-99. (available at: https://www.researchgate.net/publication/23944827 Factors Affecting Beef Cow-Herd Costs Production and Profits).

27. Otte J., Costales, A., Dijkman, J., Pica-Ciamarra, U., Robinson, T., Ahuja, V., Ly, C., Roland-Holst D. (2012): Livestock sector development for poverty reduction: an economic and policy perspective - Livestock's many virtues. FAO, Rome, ISBN 978-92-5-107242-4. (available at: http://www.fao.org/docrep/015/i2744e/ i2744e00.pdf).

28. Qushim, B., Gillespie, J., McMillin (2016): Meat Goat Enterprise Efficiency Analysis in the Southeastern United States. Journal of Agricultural and Applied Economics, EISSN 2056-7405, Volume 48, Issue 1, DOI: 10.1017/aae.2016.1, pp. 52-72. (available at: https://www.cambridge.org/core/services/aop-cambridgecore/content/view/S1074070816000018).

29. Tess, M.W., Kolstad B.W. (2000): Simulation of cow-calf production systems in a range environment: II. Model evaluation. Journal of Animal Science, ISSN $0021-$ 8812, Volume 78, Number 5, doi:/2000.7851170x, pp. 1170-1180. (available at: https://dl.sciencesocieties.org/publications/jas/abstracts $/ 78 / 5 / 1170$ ?access $=0 \&$ vie $\underline{\mathrm{w}=\mathrm{pdf})}$.

30. Stott, A. W., Milne, C. E., Goddard, P. J., Waterhouse, A. (2005): Projected effect of alternative management strategies on profit and animal welfare in extensive sheep production systems in Great Britain. Livestock Production Science, ISSN 1871-1413, Volume 97, Issues 2-3, doi:10.1016/j.livprodsci.2005.04.002, 
pp. 161-171. (available at: http://www.sciencedirect.com/science/article/pii/ $\underline{\mathrm{S} 030162260500103 \mathrm{X}) .}$

31. Ward, C. E., Vestal, M. K., Doye, D. G., Lalman, D. L. (2008): Factors Affecting Adoption of Cow-Calf Production Practices in Oklahoma. Journal of Agricultural and Applied Economics, EISSN 2056-7405, Volume 40, Issue 3, pp. 851-863. (available at: http://ageconsearch.umn.edu/bitstream/47263/2/jaae-40-03-851. pdf).

\title{
EKONOMSKA EFEKTIVNOST EKSTENZIVNE STOČARSKE PROIZVODNJE U EVROPSKOJ UNIJI
}

\author{
Lana Nastic ${ }^{5}$, Todor Markovic ${ }^{6}$, Sanjin Ivanović ${ }^{7}$
}

\begin{abstract}
Apstrakt
Različiti tipovi ekstenzivne stočarske proizvodnje su prisutni svuda u svetu, prvenstveno $u$ regionima gde se mogu koristiti prirodni resursi, kao što su pašnjaci $i$ livade. Ekstenzivna stočarska proizvodnja je takođe široko rasprostranjena i u Evropskoj uniji. Zbog toga je cilj ovog istraživanja bio da se utvrdi ekonomska efektivnost različitih tipova ekstenzivne stočarske proizvodnje $i$ da se uporedi sa efektivošću intenzivne stočarske proizvodnje. Da bi se taj cilj ostvario korišćena je FADN (Farm Accountancy Data Network) metodologija. Izvori podataka su bili FADN baza podataka Evroske unije, kao i odgovarajuće sektorske analize i publikacije Evropske komisije. Utvrđeno je da je ovčarska i kozarska proizvodnja konkurentna sa intenzivnim tipovima stočarske proizvodnje (proizvodnja mleka i nepreživari - svinje i živina). Utvrđeno je da govedarska proizvodnja (koja se ne odnosi na proizvodnju mleka) nije ekonomski efikasna usled niskog nivoa outputa koji ostvaruje.
\end{abstract}

Ključne reči: ekstenzivna stočarska proizvodnja, FADN, produktivnost, rentabilnost

5 Lana Nastić, istraživač saradnik, Institut za ekonomiku poljoprivrede, Volgina ulica br. 15, 11060 Beograd, Republika Srbija, Telefon: +381 116972 852, E-mail: lana_n@iep.bg.ac.rs.

6 Vanredni profesor, dr Todor Marković, Univerzitet u Novom Sadu, Poljoprivredni fakultet, Trg Dositeja Obradovića br. 8, 21000 Novi Sad, Republika Srbija, Telefon: +381 214853 500, E-mail: todor.markovic@polj.edu.rs

7 Vanredni profesor, dr Sanjin Ivanović, Univerzitet u Beogradu, Poljoprivredni fakultet, Nemanjina ulica br. 6, 11080 Zemun, Republika Srbija, Telefon: +381 1144 13 426, E-mail: sanjinivanovic@agrif.bg.ac. 